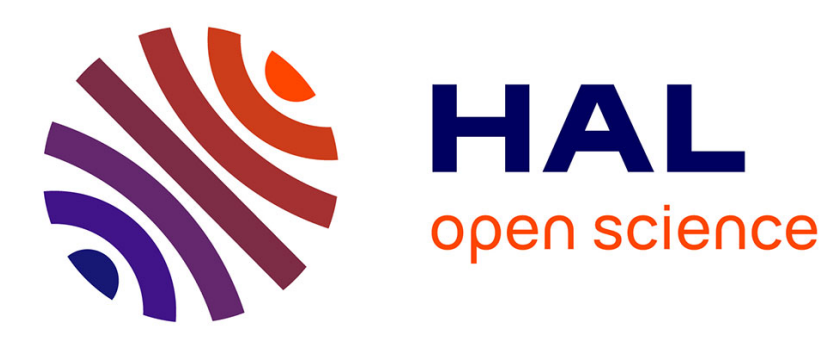

\title{
EQUATION OF STATE OF SOLID CHLORINE AND BROMINE
}

\author{
E.-Fr. Düsing, W. Grosshans, W. Holzapfel
}

\section{To cite this version:}

E.-Fr. Düsing, W. Grosshans, W. Holzapfel. EQUATION OF STATE OF SOLID CHLORINE AND BROMINE. Journal de Physique Colloques, 1984, 45 (C8), pp.C8-203-C8-206. 10.1051/jphyscol:1984837 . jpa-00224337

\section{HAL Id: jpa-00224337 https://hal.science/jpa-00224337}

Submitted on 1 Jan 1984

HAL is a multi-disciplinary open access archive for the deposit and dissemination of scientific research documents, whether they are published or not. The documents may come from teaching and research institutions in France or abroad, or from public or private research centers.
L'archive ouverte pluridisciplinaire HAL, est destinée au dépôt et à la diffusion de documents scientifiques de niveau recherche, publiés ou non, émanant des établissements d'enseignement et de recherche français ou étrangers, des laboratoires publics ou privés. 


\title{
EQUATION OF STATE OF SOLID CHLORINE AND BROMLNE
}

\author{
E.-Fr. Düsing, W.A. Grosshans and W.B. Holzapfel \\ Fachbereich Physik, Universitat-GH-Paderborn, D-4790 Paderbon, F.R.G.
}

Résumé - Le chlore et le brome ont étẽ étudiés par rayons $X$ en dispersion d'energie a des pressions jusqu' $45 \mathrm{GPa} a \mathrm{a} 300 \mathrm{~K}$. Leurs pressions de dissociation noleculaire sont estimées en comparant nos mesures avec les résultats dêjà publiês.

Abstract - Chlorine and bromine have been studied by energy dispersive $X$-ray diffraction under pressure up to $45 \mathrm{GPa}$ at room temperature. A comparison of these data with the earlier results for jodine is used for an estimate of the molecular dissociation pressures $\mathrm{P}_{\mathrm{t}}$ for bromine and chlorine.

\section{INTRODUCTION}

Chlorine, bromine and iodine crystallize at room temperature and about $4 \mathrm{GPa}$ in the same orthorhombic structure ( $D_{2}^{1}$ - Cmca) and are nomally considered as simple molecular crystals (1).

Earljer investigations of iodine under pressure report two transitjons up to $30 \mathrm{GPa}$ : I) a continuous transition into a metallic state (2-6) around $18 \mathrm{GPa}$ and 11 ) a first order structural transition at $20 \mathrm{GPa}$ with molecular dissociation to a monoatomic form $(7,8)$. A similar behaviour can be expected also for bromine and chlorine and the present study intends to give first estinates for the respective transition pressures in these substances.

\section{EXPERIMENTAL}

Chlorine and bromine were investigated up to $45 \mathrm{GPa}$ in a gasketed diamond anvil cell by energy dispersive $X$-ray diffraction with synchrotron radiation. The experimental techniques have been described in detail elsewhere (9). The solid samples of chlorine and bromine were filled into the gasket at liquid nitrogen temperatures (10). The use of nitrogen as pressure transmitting medium leads to nearly hydrostatic conditions over the whole pressure range (9). The pressure was measured by the Ruby $R_{1}$-fluorescence method with the calibration constant of $365 \mathrm{pr} / \mathrm{GPa}(11)$.

\section{RESULTS}

Neither chlorine nor bromine show phase transitions in the pressure range up to $45 \mathrm{GPa}$ at room temperature. The compression of chlorine and bromine is represented in fig. I together with previous data (8) for iodine, whereby the unit cell volume $V$ for each element is scaled by the bond length $L$ of the free molecules to arrive at scaled volunina $\bar{V}=V / L^{3}$, which $a I l o w$ for a better comparison in corresponding states.

If one fits these room temperature equation of state data with the two parameter Birch equation (12) using the known scated volume at ambient condition $V_{R T}^{0}$, one obtains for the bulk moduli at ambient condition $B_{R T}^{0}$ and for their pressure dependences $B^{\circ}$ the values which are giveft in the second and third colurim of table 1 . 


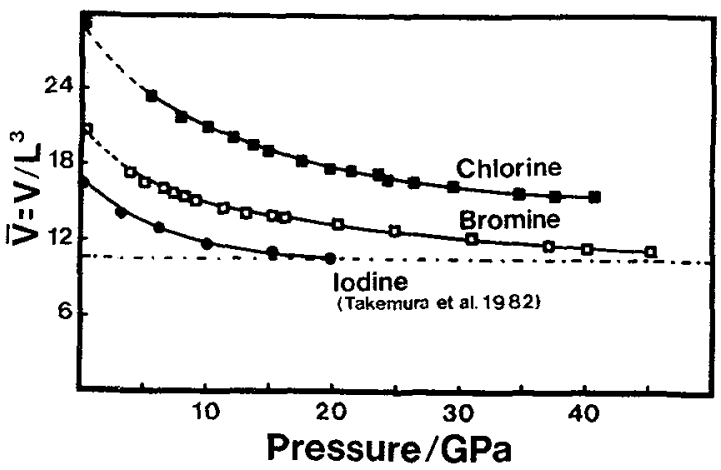

Fig. 1: Room temperature equations of state for solid chlorine, bromine and iodine. The broken lines represent the liquid phase. The dashed-dotted line indicates the volume for the molecular dissociation in iodine.

\begin{tabular}{|l|l|l|l|l|}
\hline \multirow{2}{*}{} & \multicolumn{2}{|c|}{ Two parameter fit } & \multicolumn{2}{|c|}{ One parameter fit with $\mathrm{B}^{\mathrm{O}}=5.2$} \\
\cline { 2 - 5 } & $\mathrm{B}^{01}$ & $\mathrm{~B}_{\mathrm{RT}}^{\mathrm{O}} / \mathrm{GPa}$ & $\mathrm{B}_{\mathrm{RT}}^{0} / \mathrm{GPa}$ & $\mathrm{B}_{\mathrm{O}}^{0} / \mathrm{GPa}$ \\
\hline $\mathrm{C} 1$ & $4.3(9)$ & $14.2(24)$ & $11.7(9)$ & $13.1(9)$ \\
\hline $\mathrm{Br}$ & $5.6(8)$ & $12.2(20)$ & $13.3(7)$ & $14.3(7)$ \\
\hline $\mathrm{I}$ & $5.2(7)$ & $13.6(11)$ & $13.6(2)$ & $14.5(3)$ \\
\hline
\end{tabular}

Table 1: Comparison of bulk moduti.

The large statistical errors of these values in table 1 result from a strong correlation of $\mathrm{B}^{\mathrm{O}}$ and $\mathrm{B}^{\mathrm{O}_{1}}$ in a Birch $\mathrm{fit}$. These correlations are $i l l u s t r a t e d$ in fig. 2, which represents the loci of constant standard deviations as "error ellipsoids". This figure shows more clearly than tab. 1 that the expected systematics of $B{ }^{O}$ and $B{ }^{1}$ may be just masked by their strong correlations. It appears therefore more reasonable to compare the $B_{\mathrm{RT}}^{0}$-values, which are obtained by a one parameter fit using a constant average ${ }^{2} T_{\text {value for }}{ }^{O c}$, as indicated by the vertical line in fig. 2. The value $B^{0 i}=5.2$ leads then to the data in the fourth column of table 1. Since the melting temperatures of chlorine and bromine are below room temperature at ambient pressure, one may want to compare the bulk moduli of these elements at zero pressure and temperature: $B_{0}^{0}$. These values are derived from the values of $B_{R T}$ by corrections for the thermat pressure and are compiled in the last column of tab. 1, which shows apparently the same systematic variation of the $B_{0}^{O}$ as for $B_{R T}^{O}$, however, stil1 with large uncertainties.

Since the approach to the monoatomic phase is characterized first of all by a continuous decrease of the asymmetry in the bonding within the b-c-plain of the orthorgombic lattice $(8)$, one can define an asymmetry parameter $\Delta=\left[(\mathrm{b} / 2 \mathrm{~L})^{2}+\right.$ $\left.(C / 4 L)^{2}\right]^{1 / 2}-1$, which tends to zero when all the bonds in the b-c-plain of the 


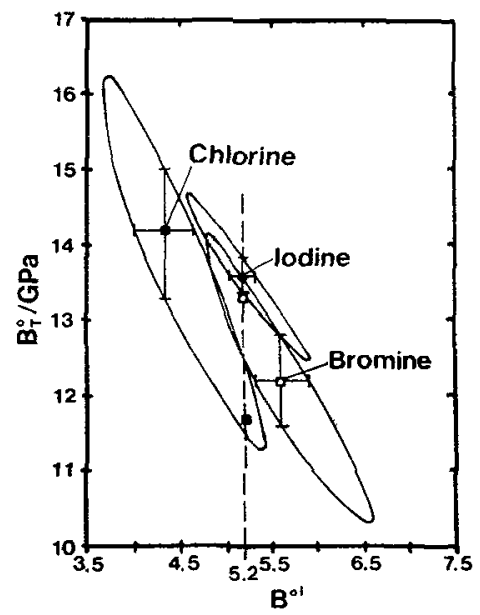

Fig. 2: Contours of constant standard deviation for the bulk moduli

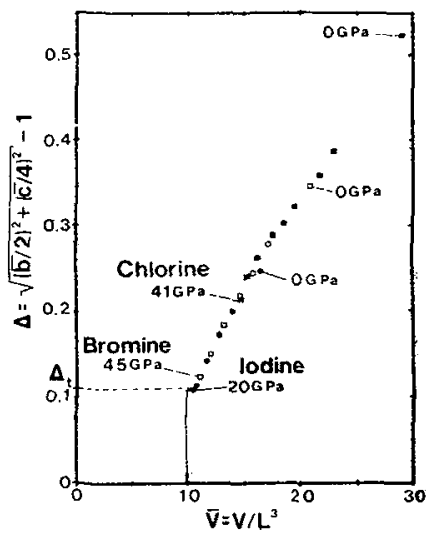

Fig. 3: Variation of the asymmetry parameter $\Delta$ for chlorine, bromine and jodine with respect to the scaled volumina $\bar{V}$.

orthorhombic lattice would approach the value $L$ of the free molecules. Fig. 3 shows in fact that this parameter decreases strongly in iodine under pressure down to a critical value $\Delta_{t}=0.11$ at the first order phase transition to the monoatomic phase. For a reasonable comparison with bromine and chlorine, fig. 3 represents the variation of these asymmetry parameters with respect to the scaled volumina $\bar{V}$. Apparently fig. 3 shows a common variation for all three substances and one may therefore speculate that also bromine transform at the same value $\Delta_{t}=0.11$ into monoatomic phases. This assumption gives as first estimates for these transition pressures $P_{t}=58(6) \mathrm{GPa}$ for bromine and $\mathrm{P}_{t}=140(30) \mathrm{GPa}$ for chlorine in good agreement with recent Raman studies on these substances (13).

This work was performed with synchrotron radiation at HASYLAB, DESY and supported in part by the Bundesministerium für Forschung und Technologie.

\section{REFERENCES:}

1) J. Donohue, The Structures of the Elements (John Wiley \& Sons, New York, 1974) p. 396

2) A.S. Balchan and H.G. Drickamer, J. Chem. Phys. 34, 1948 (1961)

3) B.M. Riggleman and H.G. Drickamer, J. Chem. Phys. 37, 446 (1962)

4) B.M. Riggleman and H.G. Drickamer, J. Chem. Phys. 38,2721 (1963)

5) R.W. Lynch and H.G. Drickamer, J. Chem. Phys. 45, 1020 (1966)

6) O. Shimomura, K. Takemura, Y. Fujii, S. Minomura, M. Mori, Y. Noda and Y. Yamada, Phys. Rev. B 18,715 (1978)

7) K. Takemura, Y. Fujii, S. Minomura and 0. Shimomura, Solid State Comm. 30 , 137 (1979)

8) K. Takemura, S. Minomura, 0. Shimumura, Y. Fujii and J.D. Axe, Phys. Rev. B 26, 998 (1982) 
9) W.A. Grosshans, E.-F. Düsing and W.B. Holzapfel, High Temp., High Press. (in press)

10) P.G. Johannsen, W. Helle and W.B. Holzapfel, this conference

11) G.J. Piermarini, S. Block, J.D. Barnett and R.A. Forman, J. Appl. Phys. 46, 2774 (1975)

12) F. Birch, Phys. Rev. 71, 809 (1947)

13) P.G. Johannsen, E.-F. Düsing and W.B. Holzapfel, in Int. Symp. on Solid State Physics under Pressure, ed. S. Minomura (Terra Scientific Publishing Corporation, Tokyo), Izu-Nagaoka (1984), in press 